\title{
Uganda's anti-gay law worries doctors and researchers
}

$\mathrm{C}$ oncerns have been mounting in Uganda's hospitals and clinics since Western donors began leaving the country to protest a new law making homosexuality a crime punishable by years in prison. The World Bank has put a US\$90-million loan on hold, and several European countries have suspended donations, but Ugandan President Yoweri Museveni has reacted defiantly. At a demonstration in March, he told thousands who marched through the streets of Kampala celebrating the law's passage that the cutbacks were "contemptuous."

But at Kampala's Mulago National Referral Hospital, doctors are apprehensive about what will happen to clinical programs and research projects involving people with HIV or AIDS, though some are reluctant to voice their concerns in public or discuss the issue with journalists.

Their worries were heightened on Apr. 3 after police raided the Makerere University Walter Reed Project, which does HIV vaccine research and runs a mobile male-circumcision clinic. An employee of the US-funded project was arrested for allegedly "conducting 'unethical research' and 'recruiting homosexuals,' " stated the US Department of State. Operations are now "temporarily suspended to ensure the safety of staff," according to the project website.

Uganda's government spokesperson, Ofwono Opondo, tweeted the day after the raid: "Police burst Walter Reed Project in Makerere University\#training youths in homosexuality."

The raid has raised concerns among clinicians and researchers, not only for their programs, but also for patients and research subjects, given the possible seizure of confidential records at the time of the arrest. There are also fears about which program could be targeted next.

The law has already had a chilling effect on physicians in leadership positions. Dr. Margaret Mungherera, president of the World Medical Association, says that before the law passed, she and other members of the Uganda Medical Association (she is a former president) publicly criticized a clause that would have required doctors to report patients who said they were homosexuals. The

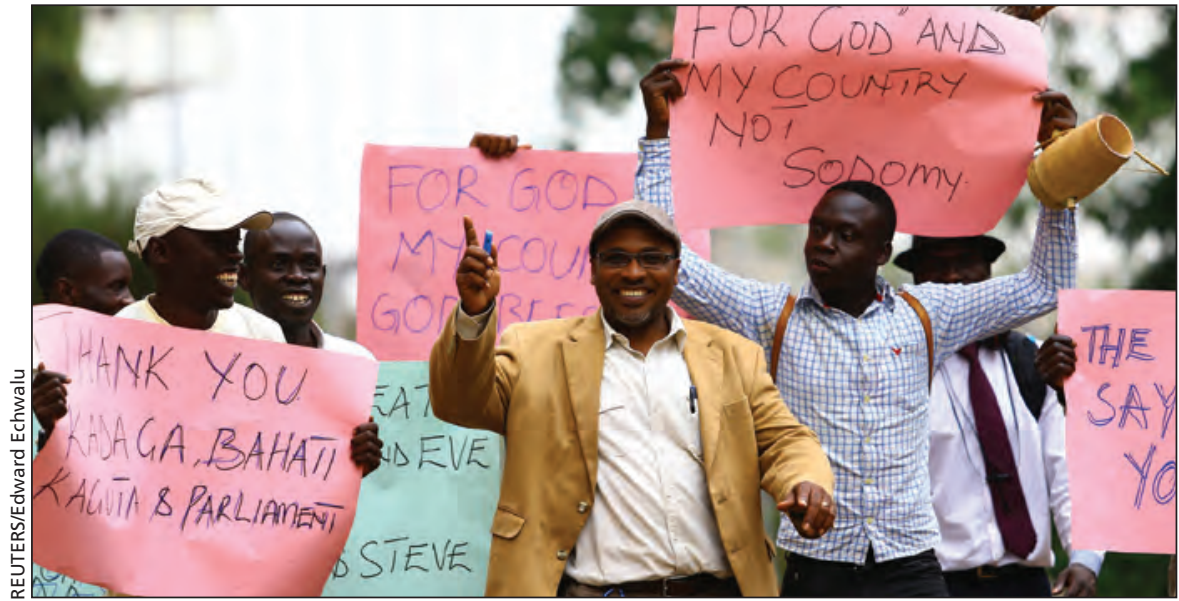

Anti-gay supporters in Kampala, Uganda celebrated a new law that imposes harsh penalties for homosexuality.

clause was removed, but Mungherera says the Uganda Medical Association has decided to no longer speak about the law publicly.

Uganda's medical programs have experienced these sorts of cuts in aid before, and physicians have seen the effects on their most vulnerable patients. Dr. Adrian Kamulegeya, an oral surgeon at Mulago Hospital, remembers when revelations of government corruption led to restrictions on donor aid in 2009. "We ended up having funds cut off, and we actually saw most of those centres that were taking HIV/AIDS people no longer taking new patients, because they did not have the medication," he says.

At the time, Kamulegeya was researching whether ranulas in the mouths of HIV-positive individuals signaled progression of disease. After examining patients, he would send them to other clinics to have CD4 and CD8 counts done free of charge. "Then I would have the evidence to actually say, 'This person might not have shown clinical AIDS, but we need to link them to treatment.'"

When funds were withdrawn, the clinics stopped providing the tests, telling Kamulegeya to "let the patient go to their nearest centre and see if they will sort that out," but he is not convinced the patients received care. He also had to stop his study because the tests were unavailable, though he was able to publish the data he had. Today, clinicians with HIV/AIDS programs at his hospital feel that they cannot speak to a journalist. "There is a kind of fear hanging over them since they don't know how their opinions would be taken by the important people," Kamulegeya wrote in an email.

Edward Mills, Canada Research Chair in Global Health at the University of Ottawa in Ontario, believes the cutbacks will not have the same devastating effects this time. In 2009, he says, the Global Fund to Fight AIDS, Tuberculosis and Malaria had almost collapsed. The worldwide economic recession combined with the change in the US presidency left the funding situation in Uganda "much more uncertain" than it is now. Mills thinks the greater threat to patients is "mob justice" — individuals being attacked because they are believed to be gay.

Even if programs remain in place, the new law could lead vulnerable individuals to avoid seeking care. Mungherera, a psychiatrist and a clinical administrator at Mulago Hospital, is especially worried about adolescents struggling with sexuality. "Many young people come to us as mental health professionals," she says. "They should be able to talk to someone." — Miriam Shuchman, Kampala, Uganda

CMAJ 2014. DOI:10.1503/cmaj.109-4782

\section{More News online}

To read more CMAJ news articles, visit cmaj.ca/site/home/news.xhtml 